\title{
Anoxia Tolerance During Vertebrate Development - Insights from Studies on the Annual Killifish Austrofundulus limnaeus
}

\author{
Jason E. Podrabsky ${ }^{1}$, Claire L. Riggs ${ }^{1}$ and Jeffrey M. Duerr ${ }^{2}$ \\ ${ }^{1}$ Portland State University, \\ ${ }^{2}$ George Fox University, \\ USA
}

\section{Introduction}

With a rare few exceptions, vertebrates are extremely sensitive to a lack of oxygen and can survive for only brief episodes of oxygen deprivation (Nilsson and Lutz, 2004). In fact, when differences in body temperature are taken into account, endotherm and ectotherm vertebrates share a very similar survival time in anoxia, and similar symptoms of cellular and tissue damage and death (Nilsson and Lutz, 2004). Thus, there appears to be a common limit to survival of anoxia in most vertebrates that may be supported by common limits to metabolic and physiologic systems. The few exceptions to this rule (all aquatic vertebrates) have developed novel mechanisms to support tolerance of long-term anoxia (Nilsson and Lutz, 2004; Podrabsky et al., 2007).

It has long been appreciated that fetal and neonatal mammals can tolerate much longer exposures to anoxia when compared to their adult counterparts (e.g. Kabat, 1940; Fazekas et al., 1941; Glass et al., 1944; Adolph, 1969). In fact, for the great majority of vertebrates, tolerance of anoxia is highest in the earliest developmental stages and is progressively lost during development (Fig. 1). This relationship is surprisingly consistent among a wide diversity of lineages and reproductive strategies with a correlation coefficient of -0.87 when data for all "typical" vertebrates are included. Embryos of the annual killifish Austrofundulus limnaeus clearly exhibit a different level ( 2 orders of magnitude greater) and pattern (increase in anoxia tolerance during early development) of anoxia tolerance compared to the other vertebrates for which data exist (Fig. 1). Embryos of A. limnaeus gain and then lose the ability to survive prolonged bouts of anoxia as a normal part of their developmental program (Podrabsky et al., 2007; Fig. 1). This unique life history pattern allows for the biological mechanisms that support tolerance of anoxia to be studied in a comparative context within a single species. In addition, these embryos respond to anoxia using the same basic metabolic pathways used by more typical vertebrates, and yet they can survive for months without oxygen. This fact suggests that novel mechanisms of anoxia tolerance that have not been explored in other systems may be operating or be induced in this species. Thus, a deeper understanding of the mechanisms that underlie tolerance of anoxia in this species has the potential to transform our understanding of anoxia tolerance, and may lead to new 
avenues for minimizing or preventing damage due to restriction of oxygen during vertebrate development, and as a consequence of heart attack or stroke.

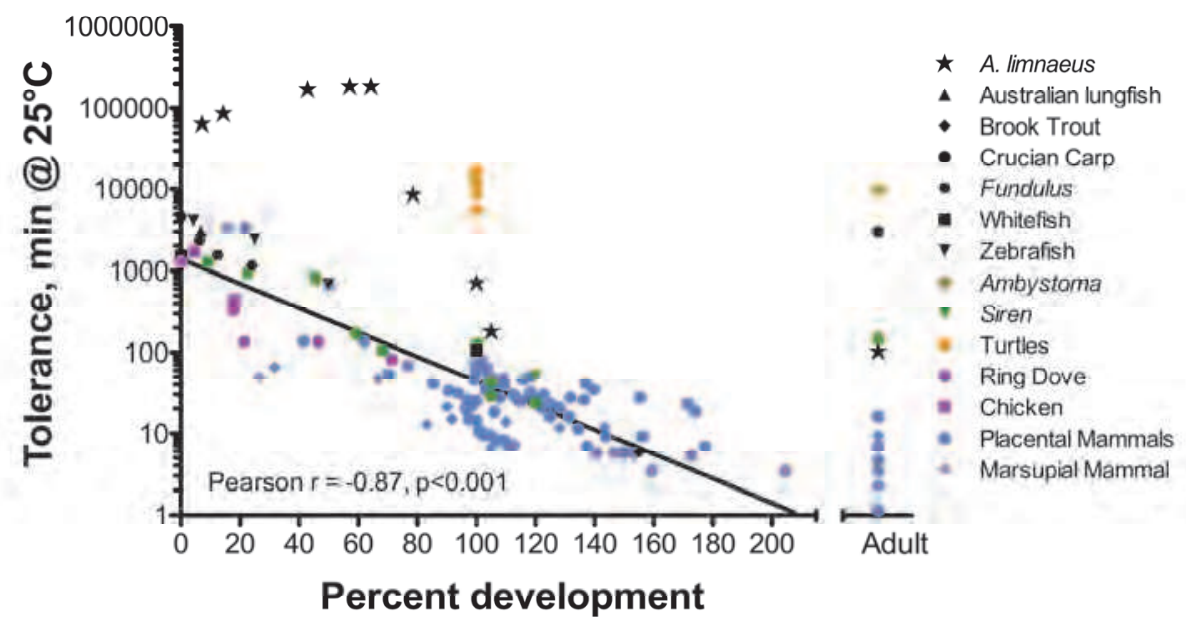

Fig. 1. Tolerance of anoxia declines during normal development in a wide variety of vertebrate embryos. Embryos of Austrofundulus limnaeus are unique among vertebrates in their extreme tolerance of anoxia beyond that predicted as a consequence of developmental stage. Survival values have been corrected for body or experimental temperature to a common temperature of $25^{\circ} \mathrm{C}$ assuming a $Q_{10}$ of 2 . The regression line was calculated based on all species and developmental stages excluding the two obvious outliers, embryos of the annual killifish A. limnaeus and turtle hatchlings. 100\% of development was set at birth or hatching for turtles, birds and placental mammals, emergence from the pouch for the Virginia opossum, and at completion of larval development for fish and amphibians. Data were taken from: A. limnaeus adults and larvae, Podrabsky (new data) and embryos, Podrabsky et al., 2007; Australian lungfish (Neoceratodus forsteri), Mueller et al., 2011; brook trout (Salvelinus fontinalis), Shepard, 1955; crucian carp (Carassius carassius) and adult turtles (Trachemys scripta, Chrysemys picta), Nilsson and Lutz, 2004; Fundulus sp., Loeb, 1894; whitefish (Coregonus clupeiformis), Hall, 1925; zebrafish (Danio rerio), Mendelsohn et al., 2008; salamanders (Ambystoma sp.), Rose et al., 1971, Weigmann and Altig, 1975, Adolph, 1979; Siren intermedia, Weigmann and Altig, 1975; turtle hatchlings (Graptemys geographica, Chelydra serpentine, Trachemys scripta, Chrysemys picta, Emydoidea blandingii, Malaclemys terrapin, Terrapene ornate), Dinkelacker et al., 2005; ring dove (Streptopelia risoria) Riddle, 1924; chicken (Gallus gallus), Nelson, 1958 and Di Carlo and Litovitz, 1999; dog (Canis lupus familiaris), Kabat, 1940; dog, cat (Felis catus), ground squirrel (Citellus tridecemlineatus), rat (Rattus norvegicus), golden hamster (Mesocricetus auratus), Adolph, 1969; guinea pig (Cavia porcellus) and rabbit (Oryctolagus cuniculus), Glass et al., 1944; sheep (Ovis aries), Dawes et al., 1959; rabbit blastocysts, Daniel, 1968; rhesus macaque (Macaca mulatta), Dawes et al., 1960; mouse (Mus musculus), Ingalls et al., 1950; Virginia opossum (Didelphis virginiana), Rinka and Miller, 1967. 


\section{The life history of Austrofundulus limnaeus}

Annual killifish are a group of teleost fish that have evolved to survive in ephemeral ponds in regions of Africa and South America that experience pronounced dry and rainy seasons. Populations persist in isolated ponds due to production of drought-tolerant embryos that can enter embryonic diapause (Wourms, 1972a, 1972b; Podrabsky et al., 2010b). Embryos may be exposed to a variety of environmental extremes during their normal development including severe hypoxia or anoxia from being buried in the pond sediments (Podrabsky et al., 1998). Development may be arrested at any of three distinct stages of embryonic diapause in this group of fish (diapause I, II and III), although not all species arrest in all three stages (Wourms, 1972b). In our stock of A. limnaeus, embryos routinely arrest in the laboratory at diapause II and III (Podrabsky and Hand, 1999). Although most embryos arrest in diapause II, some may bypass this stage of diapause and develop directly to diapause III (Wourms, 1972b; Podrabsky et al., 2010a). These embryos are called "escape embryos" (Wourms, 1972b) and very little is known about the physiology of their anoxia tolerance, although they appear to have a different metabolic poise when compared to embryos that enter diapause II (Chennault and Podrabsky, 2010).

Associated with early development and entry into diapause II is the acquisition of extreme tolerance of anoxia. Diapause II embryos have a lethal time to $50 \%$ mortality $\left(\mathrm{LT}_{50}\right)$ of about 65 days of anoxia at $25^{\circ} \mathrm{C}$ and some embryos can survive for over 120 days of complete anoxia (Podrabsky et al., 2007). Diapause II embryos arrest midway through development at about 25 days post-fertilization (dpf) at $25^{\circ} \mathrm{C}$. At this point in development, Wourms' stage (WS) 32, they possess the foundations of the central nervous system, including clearly defined fore-, mid-, and hindbrain regions, optic cups, otic vesicles, 38 pairs of somites, and a beating tubular heart (Wourms, 1972a, 1972b; Podrabsky and Hand, 1999). Extreme tolerance of anoxia is retained for at least 4 days of post-diapause II (dpd) development in WS 36 embryos that have much higher metabolic activity than diapause II embryos, and have experienced significant growth and differentiation in the brain, and circulatory systems (Podrabsky and Hand, 1999; Podrabsky et al., 2007). As the embryos continue to develop beyond WS 36, they lose their exceptional anoxia tolerance, and by the time embryonic development is complete they can survive for less than $24 \mathrm{hrs}$. This gain and then loss of anoxia tolerance makes $A$. limnaeus a unique and powerful model for investigation of the mechanisms that support long-term tolerance of anoxia in vertebrates.

\section{Metabolic rate depression and survival of anoxia}

The ability to reversibly enter a state of metabolic depression and to coordinately downregulate ATP production and consumption are considered hallmarks of anoxia tolerant vertebrates (Hand and Hardewig, 1996; Hand, 1998; Krumschnabel, 2000; Hochachka and Somero, 2002). In embryos of A. limnaeus anoxia induces a complete cessation of development (Podrabsky et al., 2007). Embryos in diapause II may be pre-adapted for survival of anoxia because they are already in a state of profound metabolic depression (Podrabsky and Hand, 1999). However, post-diapause II embryos are actively developing with a metabolic rate an order of magnitude higher than embryos in diapause II (Podrabsky and Hand, 1999). Embryos at 4 dpd (WS 36, LT $_{50} \sim 65$ days of anoxia) experience a $94 \%$ reduction of heat flow within 16 hrs of exposure to anoxia (Fig. 2A; Podrabsky, Menze, and Hand, unpublished data). Associated with this reduction in heat flow is an over $80 \%$ 
reduction of ATP content (Fig 2B; Podrabsky, Menze, and Hand, unpublished data). While the metabolic depression is not surprising, the large-scale loss of whole-embryo ATP is a striking result because it indicates a lack of coordination between ATP production and consumption. This is a major departure from other anoxia tolerant vertebrates, and indicates a possible novel cellular survival strategy. This is an important point, because it indicates that loss of cellular ATP does not have to lead to cell death in vertebrate cells, although it typically does in anoxia tolerant and sensitive species. Determining the cellular and molecular basis of survival in these cells despite the loss of ATP may be a promising avenue for developing novel treatments of anoxia in anoxia sensitive vertebrates such as mammals.
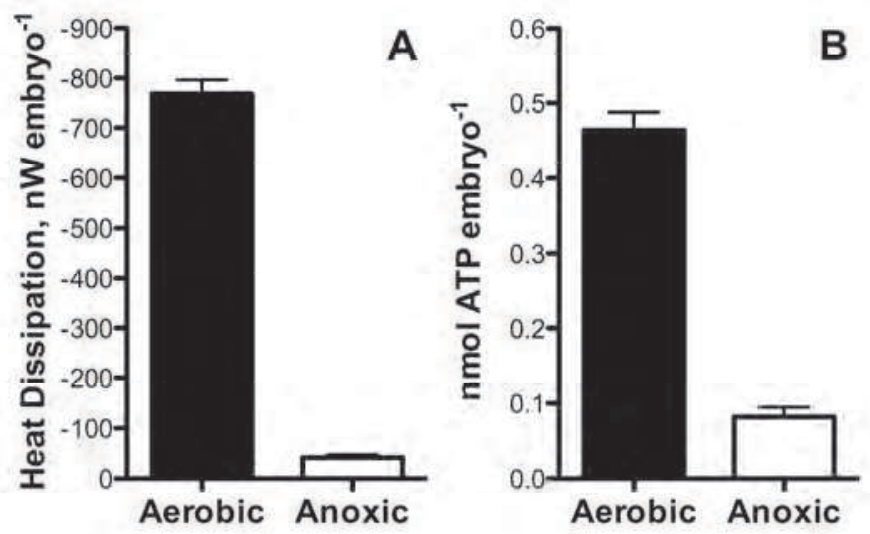

Fig. 2. Heat dissipation and ATP content of WS 36 embryos ( $4 \mathrm{dpd}, \mathrm{LT}_{50} \sim 65$ days of anoxia) exposed to $14-16$ hrs of anoxia. (A) Heat dissipation is reduced by $94 \%$ in anoxic compared to aerobic embryos. (B) Anoxia causes a decline in ATP content of over $80 \%$. (Podrabsky, Menze, and Hand, unpublished data).

\section{Heart rate during anoxia}

Exposure to anoxia or ischemia typically causes a slowing of heart rate (bradycardia) in embryonic and fetal vertebrates. This is in stark contrast to the adult response of increased heart rate (tachycardia). In embryos of A. limnaeus with maximal anoxia tolerance (WS 36) heart activity ceases within $24 \mathrm{hrs}$ of exposure to anoxia, while late embryos (WS 40) and larvae maintain a severe bradycardia until death (Fig. 3; Fergusson-Kolmes and Podrabsky, 2007). Thus, in this species extreme tolerance of anoxia is associated with the ability to reversibly pause cardiac contractility. The mechanisms that allow the cessation of heart activity, or conversely that prevent cessation of the heart in later developmental stages are currently unknown. It is possible that increased neural and endocrine control over heart function explains this difference, and the ontogeny of cardiac physiology during annual killifish development should be the focus of future studies. These data may help to inform studies of the effects of hypoxia and anoxia on the developing mammalian fetus. There is some controversy about the susceptibility of fetal hearts to hypoxic exposures, with those 
measuring cessation of heart activity finding fetal hearts more susceptible to hypoxia than adult hearts (Ostadal et al., 1999). However, it is possible that fetal hearts stop beating as an adaptive response to anoxia, which seems more consistent with the overall greater tolerance of anoxia in fetal and neonatal mammals as discussed above.

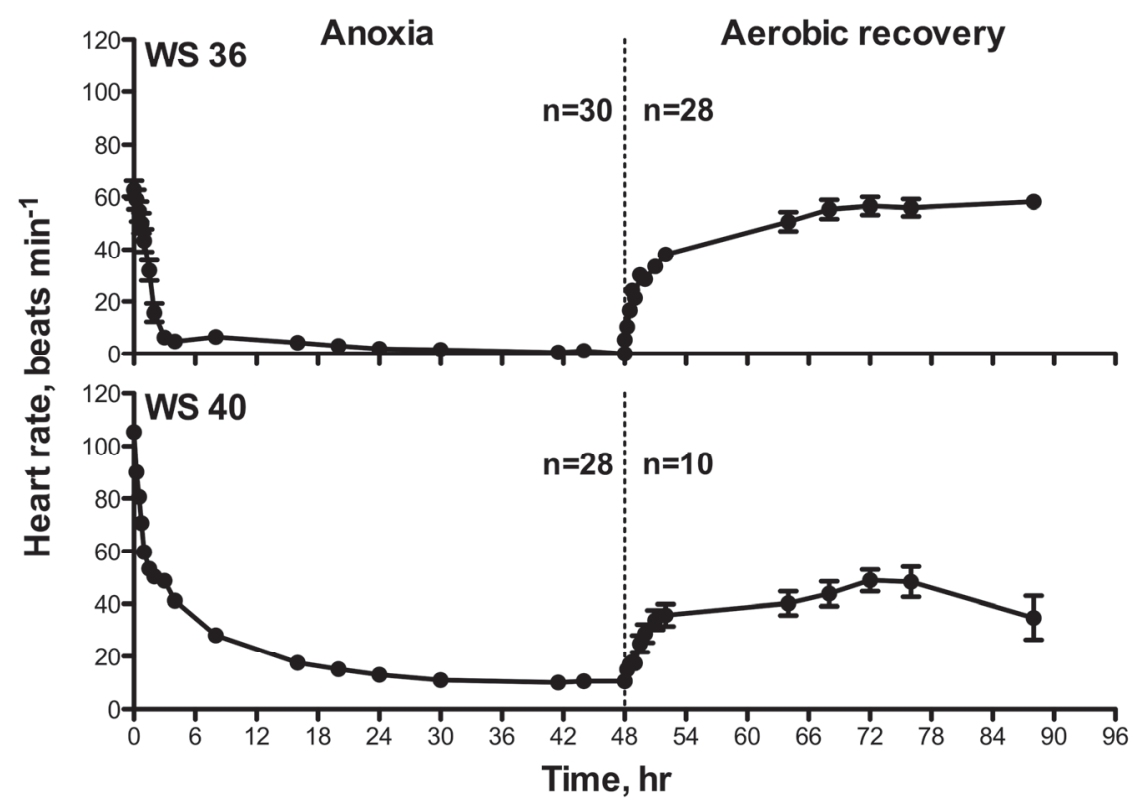

Fig. 3. Heart rate ceases in embryos with long-term tolerance of anoxia (WS 36), while embryos that have lost extreme tolerance of anoxia (WS 40) sustain a severe bradycardia in response to anoxia (Fergusson-Kolmes and Podrabsky, 2007). WS 36 (4 dpd), WS 40 (12 dpd).

\section{Anaerobic metabolism and end-product accumulation}

Anaerobic metabolism appears to be very constrained in vertebrates, with glycolytic production of lactate being the almost exclusive major end-product of anaerobic metabolism. The one major exception to this rule is the production of ethanol (in addition to a substantial amount of lactate) during exposure to anoxia in fish of the genus Carassius (goldfish and Crucian carp) and perhaps the bitterling (Shoubridge and Hochachka, 1980; Johnston and Bernard, 1983; van Waarde, 1991). However, to our knowledge no embryo or fetus has been reported to produce ethanol in response to anoxia. Embryos of A. limnaeus produce large quantities of lactate as their major anaerobic end-product (Fig. 4; Podrabsky et al., 2007). Thus, metabolic rate depression is absolutely key to the success of this survival strategy and there is a strong negative correlation between rate of lactate accumulation (a reasonable proxy for metabolic rate under anoxia) and survival times in anoxia (Fig. 5; Podrabsky et al., 2007). In addition, maximal survival times of anoxia in embryos of $A$. 
limnaeus (just over 100 days) agree well with predicted exhaustion of embryonic glycogen stores (Podrabsky et al., 2007).

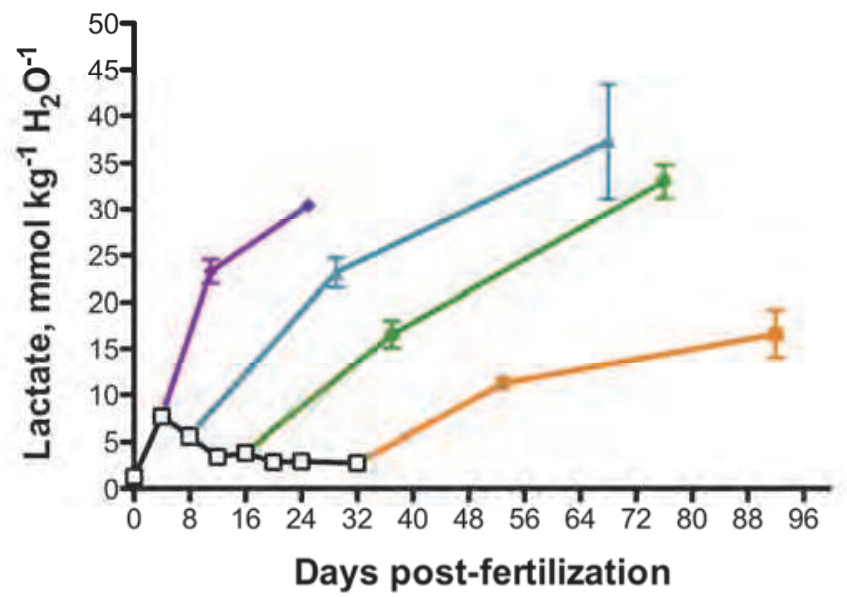

Fig. 4. Lactate is the major end-product of anaerobic metabolism in embryos of A. limnaeus. Open symbols represent normoxic values, while colored symbols represent accumulation of lactate under anoxia (Podrabsky et al., 2007).

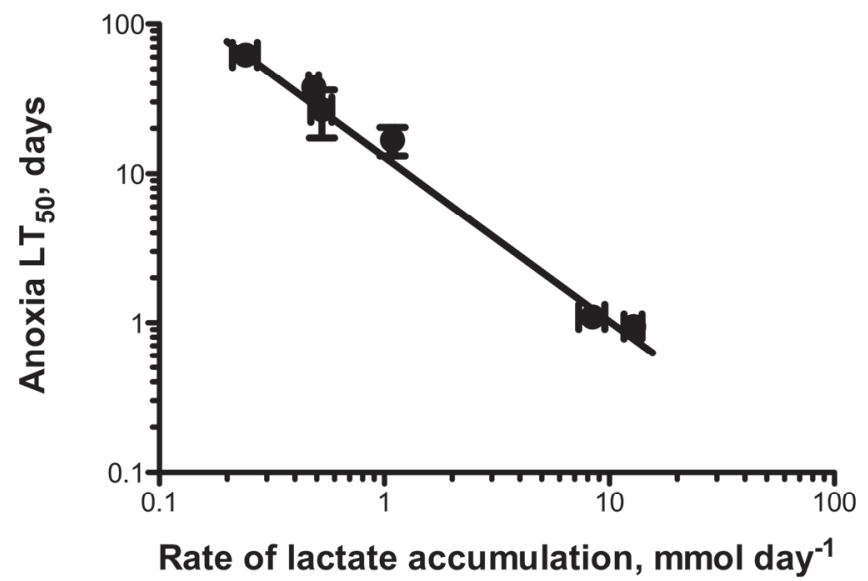

Fig. 5. The rate of lactate accumulation during exposure to anoxia is highly correlated with survival times in anoxia, supporting the importance of metabolic rate depression in survival of long-term anoxia (Podrabsky et al., 2007). 


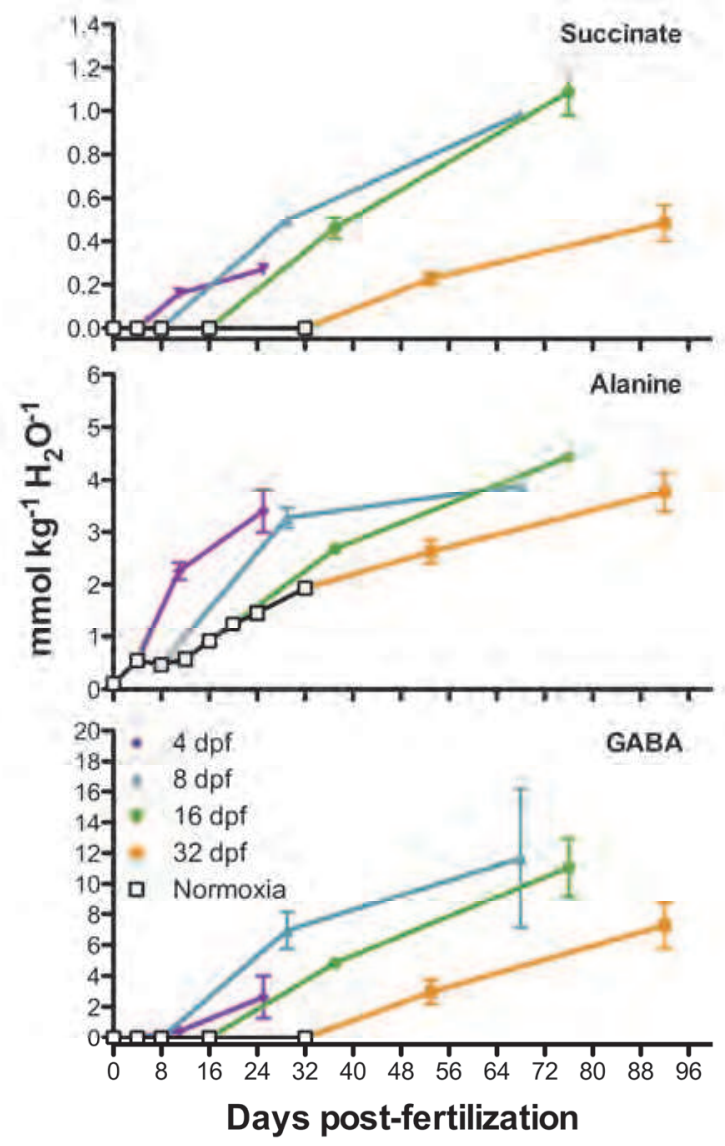

Fig. 6. Embryos of A. limnaeus accumulate succinate, alanine, and large quantities of $\gamma$ aminobutyrate (GABA) when exposed to anoxia. Open symbols represent normoxic values while colored symbols represent accumulation during exposure to anoxia (Podrabsky et al., 2007).

A. limnaeus embryos also accumulate substantial amounts of alanine, succinate, and $\gamma$ aminobutyrate (GABA) under anoxic conditions (Fig. 6; Podrabsky et al., 2007). Accumulation of succinate and alanine is common among invertebrate species that tolerate prolonged exposures to anoxia (Hochachka and Somero, 2002), and indicates that continued mitochondrial intermediary metabolism is essential to support anoxia tolerance in embryos of A. limnaeus (see below). Accumulation of GABA has been documented in the brains of adult turtles and crucian carp and has been implicated in the prevention of excitotoxic cell death through its role as an inhibitory neurotransmitter in the adult vertebrate nervous system (Nilsson and Lutz, 2004). However, the function of GABA as a neurotransmitter in the developing nervous system is complex. GABA has a generally excitatory affect on the 
developing nervous system in the few vertebrates in which it has been studied (Cherubini et al., 1991; Ben-Ari, 2002). In rats, GABA signaling is excitatory in late term fetuses and is only transiently transformed into an inhibitory neurotransmitter through the expression of specific chloride channels during the birthing process (Tyzio et al., 2006). Importantly, this change in neurotransmitter activity is associated with an increase in tolerance of oxygen deprivation that is thought to be important for survival of ischemia caused during labor. Levels of GABA are non-detectable in early embryos (through diapause II) of A. limnaeus during normoxic incubation (Podrabsky et al., 2007). When exposed to anoxia, GABA accumulates to high levels in embryos that possess extreme anoxia tolerance (Fig. 6; Podrabsky et al., 2007). These data suggest that GABA is not yet used as a neurotransmitter in these embryos, or that GABAergic neurons are in low abundance, despite the presence of a differentiated nervous system. In addition, the high levels of GABA accumulated (8-12 $\mathrm{mM}$ ) may indicate a metabolic role for the production of GABA in embryos of A. limnaeus, in addition to or instead of a role as an inhibitory neurotransmitter. Further exploration of the role of GABA in survival of anoxia, and of the development of GABA signaling pathways in the developing nervous system are needed to resolve the role of accumulation of GABA during exposure to anoxia in developing vertebrates.

\section{Mitochondrial physiology of developing embryos}

Embryos of A. limnaeus develop an impressive tolerance of anoxia as part of their normal development, even under aerobic conditions. In fact, as early embryos develop and enter diapause II, they are consistently poised for anaerobic lactate production with over 50 times the capacity for lactate dehydrogenase (LDH) compared to citrate synthase (CS) activity

(Fig. 7; Chennault and Podrabsky, 2010). Even during the highly aerobic regions of development in this species (see below) there is about 13 times more capacity for LDH activity compare to CS activity (Fig. 7). In fact, citrate synthase activity is low throughout most of embryonic development in this species, especially in those developmental stages that exhibit the greatest tolerance of anoxia. This low level of citrate synthase activity is consistent with what is known about mitochondrial physiology in this species (see below, Duerr and Podrabsky, 2010). Calorimetric:respirometric (C:R) ratios can be used as an indicator of the contribution of anaerobic metabolism to total heat production. C:R ratios indicate a significant contribution of anaerobic metabolism to total heat flow in early embryos through diapause II (Podrabsky and Hand, 1999). This anaerobic poise is lost in post-diapause II development when C:R ratios are indistinguishable from theoretical values based on a completely aerobic metabolism (Podrabsky and Hand, 1999). One strategy of these embryos may be to delay maturation of mitochondrial oxidative metabolism in order to prepare for exposures to anoxia in their natural environment. This may help to explain the slow rates of development in this species (about $38-40 \mathrm{dpf}$ at $25^{\circ} \mathrm{C}$ to hatching if diapause II is not entered) compared to species with similar sized eggs and life histories such as Fundulus heteroclitus which complete development after $11-16$ days at $20^{\circ} \mathrm{C}$ (DiMichele and Powers, 1984). There may be a trade-off between anoxia tolerance and developmental rate that is governed by the ability to retain the metabolic structure of very early embryos (cleavage and blastula stage) that relies on anaerobic rather than oxidative pathways to support development. The dependence of anoxia tolerant embryos on anaerobic metabolism even under aerobic conditions is supported by an extremely low activity of mitochondrial electron transport chain complexes and the almost complete 
absence of ATP synthase activity in mitochondria isolated from diapause II embryos (Fig. 8; Duerr and Podrabsky, 2010). In fact, the extremely low rates of oxygen consumption exhibited by mitochondria isolated from diapausing embryos can be attributed almost exclusively to proton leak (Duerr and Podrabsky, 2010). This apparent waste of metabolic fuel to maintain proton leak and therefore some small level of oxidative metabolism appears paradoxical.

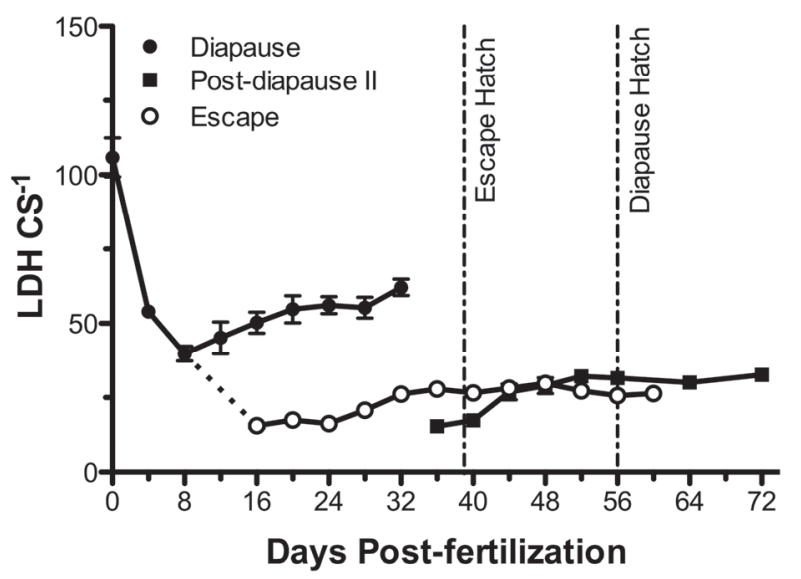

Fig. 7. Embryos of A. limnaeus have a far greater enzymatic capacity for lactate dehydrogenase activity compared to citrate synthase activity throughout development. It is especially high during early development and diapause II (Chennault and Podrabsky, 2010).

We hypothesize that mitochondria in the developing killifish are likely rather organized to support limited intermediary metabolism such as amino acid transamination, which appears to be important in the survival of A. limnaeus embryos exposed to anoxia (Podrabsky et al., 2007). For example, figure 8 illustrates that during diapause II and III, the ATP synthase (Complex V) is essentially inactive, though complexes II and IV are moderately active. Proton leak, as indicated previously, is also elevated during these same periods. One interpretation is that this is a succinate-dependent pathway for maintaining a limited proton-motive force. A nominal mitochondrial membrane potential is required for metabolite transporter function to provide substrate for the citric acid cycle and to export metabolites to the cytosol. We further hypothesize that the inner membrane of mitochondria from A. limnaeus embryos may exhibit elevated proton conductance as a mechanism to avoid extremely high membrane potentials and subsequent production of reactive oxygen species during transitions into and out of anoxia. This theory has yet to be tested experimentally. Mitochondrial densities within A. limnaeus embryos, as estimated by mtDNA content, increase by nearly four-fold as the embryos transition from diapause III to adult (Duerr and Podrabsky, unpublished data). These data clearly illustrate that the quantity and nature of mitochondria of A. limnaeus embryos are not consistent with maximal aerobic ATP production, but rather a role in supporting intermediary metabolism. 

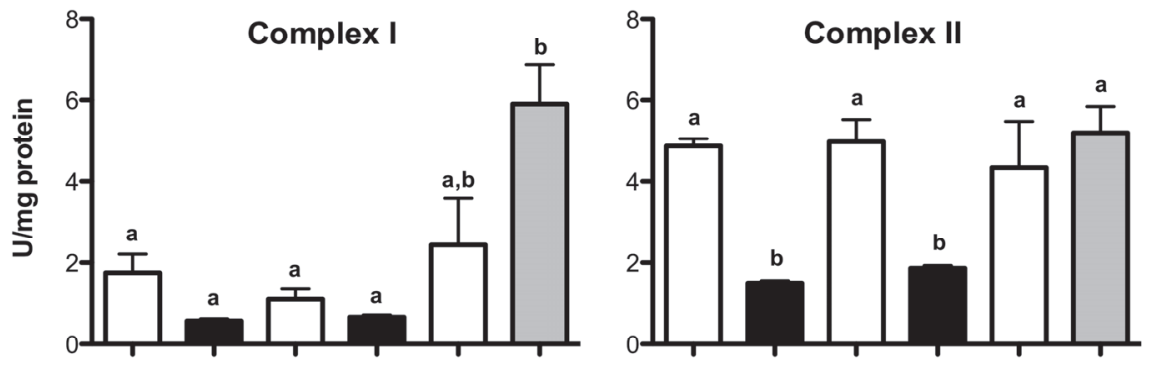

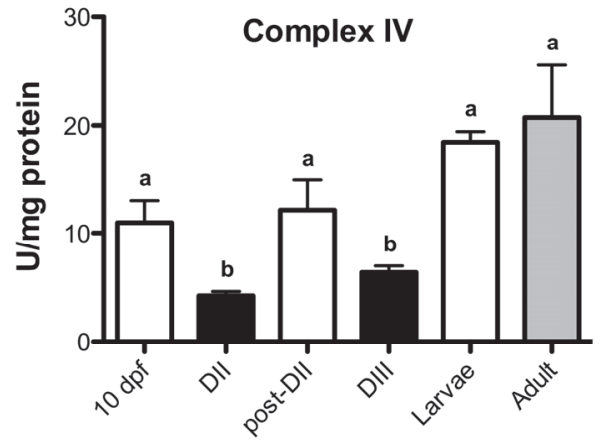

Life Stage

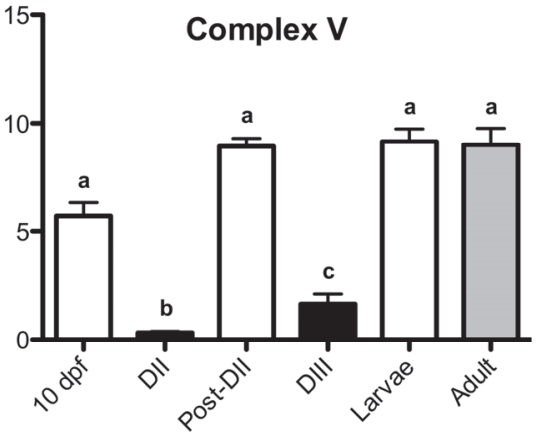

Life Stage

Fig. 8. Diapausing embryos have reduced activity of enzyme complexes involved in mitochondrial electron transport, including extremely low levels of ATP synthase (complex V) activity. DII = diapause II, DIII = diapause III, post-DII embryos are WS 39, larvae are 1-2 days post-hatch, adult data are for isolated liver mitochondria (Duerr and Podrabsky, 2010).

\section{Preconditioning and anoxia tolerance}

It has long been appreciated that short, non-lethal bouts of oxygen deprivation (ischemic or hypoxic) can induce a protective phenotype in mammalian tissues which supports reduced tissue damage and increased survival of subsequent more severe bouts of oxygen deprivation; a phenomenon known as ischemic or hypoxic preconditioning (Murray et al., 1986). Because of its clinical potential, preconditioning has been well-studied in mammalian systems, but few studies of preconditioning have been reported for other groups of vertebrates (Mulvey and Renshaw, 2000; Gamperl et al., 2001; Gamperl et al., 2004). A better understanding of the preconditioning-induced phenotype may lead to new therapies to reduce tissue damage and mortality as a result of heart attack or stroke. Preconditioning as defined in biomedical research on mammalian heart and brain tissue is very similar to induced tolerance as described by comparative physiologists. In both instances, an initial stressful event protects the organism or tissue in subsequent exposures. The advantages of this strategy are obvious, because in many situations (such as daily fluctuations in temperature, or tidal cycles) exposures to environmental stress are likely to occur repeatedly 
or intermittently. Preconditioning is very likely one manifestation of a highly conserved cellular stress response (Kültz, 2003, 2005). Thus, exploration of the cellular stress response in a variety of evolutionary lineages may shed light on the mechanisms of induced ischemia tolerance due to preconditioning.

\subsection{Anoxic preconditioning}

In embryos of $A$. limnaeus, survival of anoxia can be increased following an anoxic preconditioning (AP) regime of $24 \mathrm{hrs}$ of anoxia followed by $24 \mathrm{hrs}$ of aerobic recovery (Fig. 9). However, early post-diapause II embryos ( $4 \mathrm{dpd}$, WS 36), which have the greatest ability to survive long-term anoxia, do not experience an increase in survival following anoxic preconditioning (Fig. 9). In fact, it appears that AP causes a statistically significant decrease

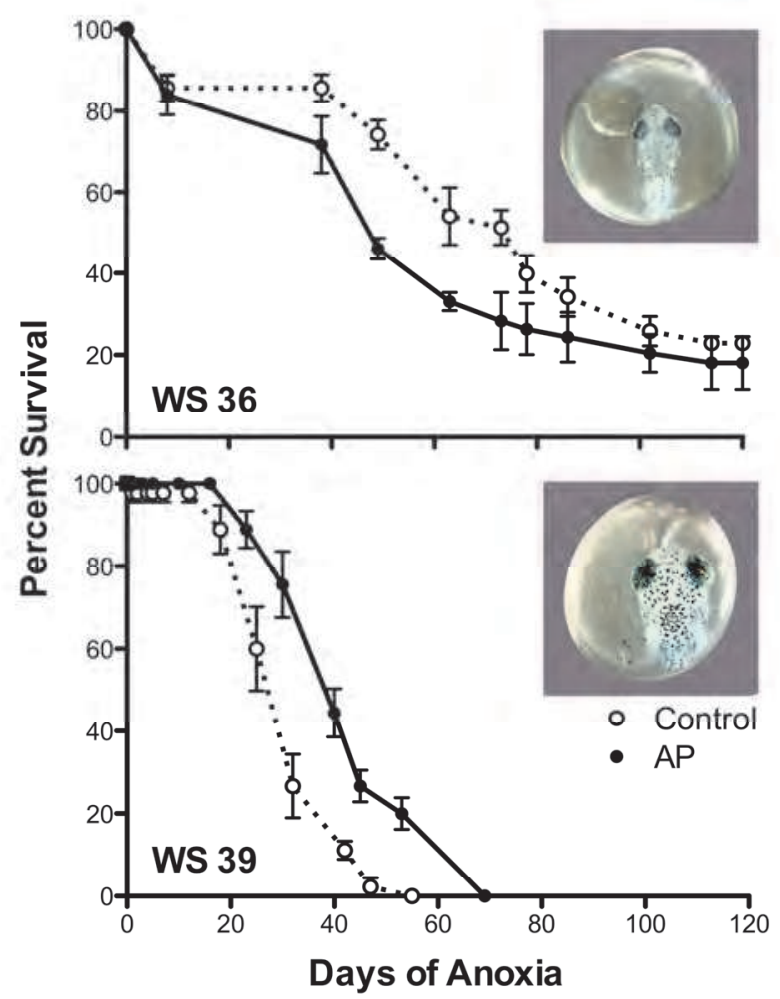

Fig. 9. Survival of embryos exposed to a single bout of long-term anoxia versus those exposed to anoxic preconditioning and then long-term anoxia at $25^{\circ} \mathrm{C}$. Control $=$ embryos incubated aerobically and then exposed directly to long-term anoxia; $\mathrm{AP}=$ embryos at same stage exposed to $24 \mathrm{hrs}$ of anoxia and then $24 \mathrm{hrs}$ of aerobic recovery prior to exposure to long-term anoxia. Embryos were exposed to anoxia as described in Podrabsky et al. (2007). Symbols represent the mean and error bars the S.E.M. ( $n=4$ groups of 20 embryos). 
in survival in this embryonic stage (Table 1). Later in development, as extreme tolerance of anoxia is lost, induction of endogenous protective mechanisms is observed (Fig 10). Both WS 39 and WS 40 embryos exhibit a significant increase in survival of anoxia following AP (Figs. 9 and 10). However, the extreme tolerance of anoxia observed in $4 \mathrm{dpd}$ embryos cannot be induced in later stage embryos, suggesting that preconditioning is a unique anoxia tolerance phenotype. Escape embryos that do not enter diapause II appear to have an equal tolerance of anoxia compared to those that reach the same developmental stage after entering diapause II (Fig. 10). This suggests that AP-induced tolerance of anoxia is not a consequence of a diapause-induced trait that is partially retained or reactivated in a WS 40 embryo, but rather is a stage-specific trait.

\begin{tabular}{|c|c|c|c|c|c|c|}
\hline \multirow[b]{2}{*}{ Stage } & \multirow[b]{2}{*}{ Preconditioning } & \multirow{2}{*}{$\begin{array}{l}\mathbf{L T}_{50}, \text { days }^{\mathbf{a}} \\
\text { Mean } \\
\end{array}$} & \multicolumn{2}{|c|}{ 95\% C.I. of $\mathbf{L T}_{50}$} & \multirow[b]{2}{*}{$\%$ Change } & \multirow[b]{2}{*}{ Sig. $b$} \\
\hline & & & Lower & Upper & & \\
\hline \multirow[t]{2}{*}{ WS 36 - post-D2 } & None & 74.3 & 65.9 & 82.7 & & A \\
\hline & Anoxia & 59.5 & 52.0 & 66.7 & -20 & $\mathrm{~B}$ \\
\hline \multirow[t]{2}{*}{ WS 38 - post-D2 } & None & 27.8 & 25.9 & 29.7 & & A \\
\hline & Anoxia & 39.1 & 37.1 & 41.1 & 41 & $\mathrm{~B}$ \\
\hline \multirow[t]{6}{*}{ WS 40 - post-D2 } & None & 6.7 & 6.1 & 7.2 & & $\mathrm{~A}$ \\
\hline & Anoxia & 8.8 & 8.3 & 9.4 & 32 & $\mathrm{~B}$ \\
\hline & None & 6.1 & 5.3 & 6.8 & & $\mathrm{~A}$ \\
\hline & Aerobic Acidosis & 6.1 & 5.3 & 7.0 & 0 & A \\
\hline & None & 5.4 & 4.8 & 6.0 & & $\mathrm{~A}$ \\
\hline & Hydrogen Sulfide & 4.4 & 4.0 & 4.8 & -18 & $\mathrm{C}$ \\
\hline \multirow[t]{2}{*}{ WS 40- Escape } & None & 6.1 & 5.8 & 6.4 & & $\mathrm{~A}$ \\
\hline & Anoxia & 9.4 & 8.9 & 10.0 & 56 & $\mathrm{~B}$ \\
\hline
\end{tabular}

aProbit regression analysis was used to determine the $\mathrm{LT}_{50}$ for each condition. $\mathrm{LT}_{50}$ values were compared for all experiments within a developmental stage, but not across developmental stages. ${ }^{b} \mathrm{LT}_{50}$ values were considered statistically different if the $95 \% \mathrm{CI}$ of their relative median potencies did not encompass 1 . A relative median potency of 1 would indicate the same effect of each treatment on median survival. Comparisons were made for all treatments within a single developmental stage, but not between stages. Means with different letters are statistically different $(\mathrm{p}<0.05)$.

Table 1. 95\% confidence intervals for lethal time to 50\% mortality derived from Probit regression analysis of survivorship data.

The highly variable and extreme environment in which these embryos survive very likely imposes severe hypoxia or even anoxia on a daily basis (Podrabsky et al., 1998). Thus, the extreme tolerance observed in early embryos, and the ability to induce protective mechanisms in later embryos is very likely adaptive in this species. Given their habitat, it is curious that high anoxia tolerance would not be retained for all of development. This suggests that there may be some trade-off between maintaining high tolerance of anoxia and completion of normal development. It is possible that the protective mechanisms and metabolic alterations (see above) that support anoxia tolerance may partially interfere with rapid cell growth and proliferation, as has been reported for over-expression of stress proteins such as HSP 70 in Drosophila melanogaster (Krebs and Feder, 1997). There is certainly a consistent trend within A. limnaeus that periods of slow developmental progression and greatly reduced normoxic aerobic metabolism have a much greater tolerance of anoxia 
(Podrabsky and Hand, 1999; Podrabsky et al., 2007). These slow periods of development are also associated with entry into diapause II and constitutively elevated levels of HSP 70 (Podrabsky and Somero, 2007). Thus, it is possible that these pathways may be at odds with fast rates of development, and thus maintenance of long-term anoxia tolerance comes at the cost of slower development.

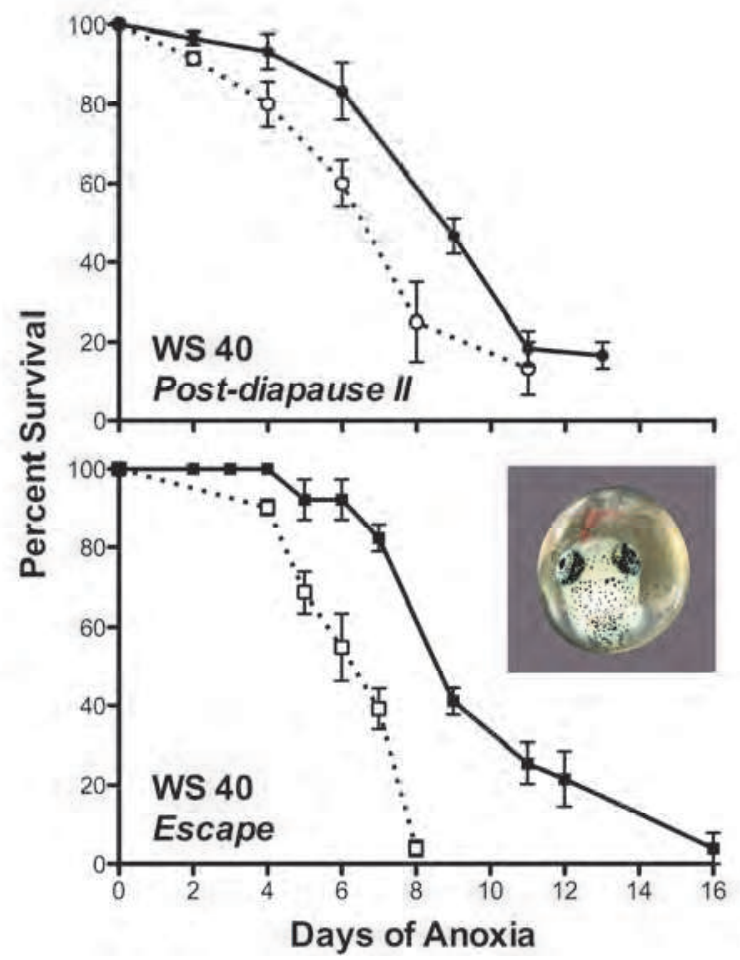

Fig. 10. Anoxic preconditioning (AP, closed symbols) can induce increased survival compared to control (open symbols) WS 40 embryos of A. limnaeus that have lost their longterm anoxia tolerance. Both embryos that entered diapause II and then resumed development, and those that escaped diapause II and reached the same stage have equivalent tolerances of anoxia and responses to AP. All experiments were conducted at $25^{\circ} \mathrm{C}$. Symbols represent the mean \pm S.E.M. ( $n=4$ groups of $14-20$ embryos).

\subsection{Aerobic acidosis preconditioning}

Aerobic acidosis is known to induce metabolic depression in other systems associated with long-term tolerance of anoxia. For instance, in brine shrimp, Artemia franciscana, aerobic acidosis can induce many of the phenotypic characters associated with metabolic depression (Hand and Carpenter, 1986). We see no affect of aerobic acidosis on increased survival following $20 \mathrm{hrs}$ of preconditioning, although there was certainly a physiological affect as determined by decreased heart rate (Fig. 11). We conclude based on these two pieces of 
evidence that the mechanisms that reduce metabolism in aerobic acidosis are distinct from those that act during anoxia. This contrasts a number of studies in mammalian tissues that report a positive effect of acidotic preconditioning on survival of subsequent ischemic or hypoxic insults (Zhai et al., 1993; Lundmark et al., 1999; Luo et al., 2008). It is not clear why we do not see a similar effect in this species, but it could indicate that the mechanisms or signals that induce preconditioning in this species are novel and represent new avenues for extending cell survival during oxygen deprivation. It is also possible that because we did not allow the embryos to recover for $24 \mathrm{hrs}$ following the aerobic acidosis, that they did not have enough time to induce the proper changes in gene expression. However, we find this unlikely because the embryos were always exposed to a normoxic environment, and would presumably still have plenty of resources available to support alterations in gene expression.

\subsection{Sodium sulfide preconditioning}

Recent evidence suggests that exposure to hydrogen sulfide can induce a state of metabolic depression in mice and can protect them from hypoxic damage (Blackstone and Roth, 2007). In addition, hydrogen sulfide signaling has been implicated as an oxygen sensing mechanism in the vasculature (Whitfield et al., 2008). Preconditioning A. limnaeus embryos with $500 \mu \mathrm{M}$ sodium sulfide under aerobic conditions had no effect on survival of anoxia (Fig. 11), although it did have a clear physiological affect as evidenced by reduced heart rate. This suggests that sulfide signaling is likely not an important mediator of anoxic preconditioning in this system, but could be important in signaling metabolic depression through alternate metabolic pathways. This again points to a novel signaling mechanisms in A. limnaeus embryos compared to the typical mammalian models. However, this was a very simplified experimental regime and perhaps using a different level of sodium sulfide or allowing the embryos to recover aerobically for $24 \mathrm{hrs}$ prior to exposing them to anoxia would alter the results.

\subsection{Anoxic preconditioning in developing vertebrates}

The concept of physiological preconditioning has been well-developed in response to short bouts of restricted blood flow (ischemia) in adult mammalian tissues and organs (e.g. Murray et al., 1986; Obrenovitch, 2008; Alchera et al., 2010; Chambers et al., 2010). This phenomenon is typified by decreased damage in oxygen sensitive tissues, increased physiological function, and increased survival of individuals suffering from an otherwise lethal dose of ischemia without prior preconditioning. These studies illustrate that short bouts of ischemia can induce a protective phenotype in a variety of tissues and organs of many mammalian species. However, most of these studies are focused on adult tissues and organs, and it is not clear that preconditioning is affective in early life history stages. For example, five $1 \mathrm{~min}$ ischemic events induced by umbilical occlusion did not result in a preconditioned phenotype in fetal sheep (Lotgering et al., 2004). Ostadalova et al. (1998) report no protective effects of ischemic preconditioning on isolated neonatal rat hearts until 7 days post-birth. They conclude that induction of protective preconditioning may not be developed until the baseline high tolerance typical of fetal and neonatal stages is lost (Ostadalova et al., 1998). Thus, the limited evidence suggests that while fetal and neonatal 


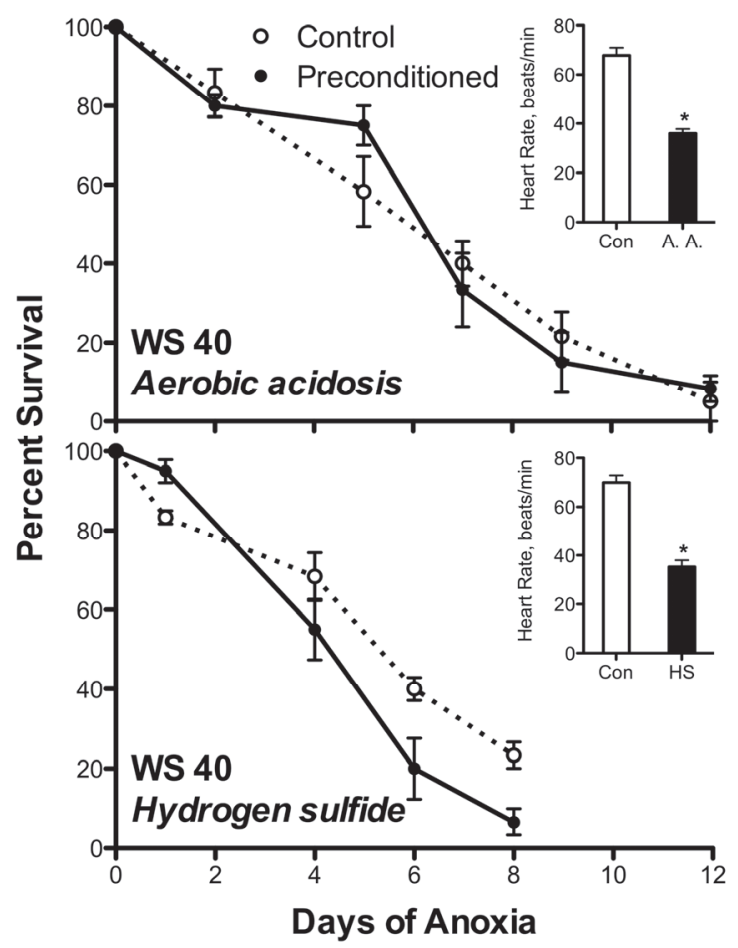

Fig. 11. Survival of A. limnaeus embryos at WS 40 that were exposed to long-term anoxia (Control) or were preconditioned with aerobic acidosis (20 hrs of exposure to $20 \% \mathrm{CO}_{2}, 80 \%$ room air) or $500 \mu \mathrm{M}$ sodium sulfide for $20 \mathrm{hrs}$ under aerobic conditions. All experiments were conducted at $25^{\circ} \mathrm{C}$. Symbols represent the mean and error bars the S.E.M. $(n=4$ groups of 20 embryos). The inset graphs for each panel report heart rate activity in beats per minute for each experimental treatment. Bars are means and error bars are S.D. ( $n=8$ embryos). Both aerobic acidosis and sodium sulfide caused a significant decline in heart rate after $20 \mathrm{hrs}$ of exposure (t-tests, $\mathrm{p}<0.001)$.

mammalian embryos have a higher overall tolerance of oxygen deprivation, they lack a strong preconditioning effect in heart tissue. However, asphyxic preconditioning does appear to induce increased survival in late term rat embryos (Strackx et al., 2010). This study exposed late gestation fetuses (embryonic day 17) to $30 \mathrm{~min}$ of ischemia by completely clamping the uterine and ovarian arteries. This treatment lead to a significant increase in survival in pups challenged with 19 min of severe asphyxia on embryonic day 22. The conflicting results reported in these two studies on rats may be due to differences in experimental methodologies. It is also possible that fetal and neonatal brain and heart tissues respond to preconditioning in different ways, and with a different time course of development. However, it is important to note that in the data presented in this study as well as in the few studies on mammalian fetal and neonatal stages, that preconditioning 
does not appear to re-establish the fetal/neonatal phenotype of substantially higher tolerance of anoxia, and thus the mechanisms that support tolerance of oxygen deprivation in early life history stages of vertebrates may be very different from the mechanisms that support protective preconditioning. This suggests that studies of both mechanisms could lead to novel insights into the prevention of damage due to oxygen deprivation.

\subsection{Evolutionary significance of anoxic preconditioning}

Ischemic or anoxic preconditioning has not been explored in many non-mammalian systems. Hypoxic preconditioning has been observed in the heart of hypoxia sensitive strains of trout, but not those that have naturally evolved an increased tolerance of hypoxia (Gamperl et al., 2001; Gamperl et al., 2004; Overgaard et al., 2004). These authors suggest that in the trout heart, hypoxia tolerance and preconditioning are not additive, which leads to the conclusion that hypoxia tolerance in this species may amount to the permanent induction of the preconditioned phenotype. This is not the case in embryos of A. limnaeus, which have a substantial tolerance of anoxia, even in late developmental stages and yet their survival can be extended through anoxic preconditioning. However, the present study and the work of Gamperl and colleagues $(2001 ; 2004)$ suggest that anoxic or hypoxic preconditioning is very likely an ancient trait that evolved at least early in the vertebrate lineage. Indeed, it may be much more ancient than that. Johnson et al. (1989) report hypoxic preconditioning of anoxia tolerance in the root tips of corn. Perhaps the anoxic/hypoxic preconditioning response is simply the induction of very ancient stress tolerance pathways that for some reason are detrimental to multicellular organisms except under conditions that limit oxygen supply. The evolutionary history of the preconditioning phenomenon has not been comprehensively addressed, and detailed studies from a variety of lineages will be needed to assess the overall importance of this response to organismal survival of anoxia or hypoxia.

\section{Conclusions}

\subsection{Anoxia tolerance during vertebrate development}

Tolerance of anoxia is generally high during early development and is subsequently lost as vertebrate embryos develop towards the adult phenotype of low tolerance. This pattern applies to species from a diversity of lineages, reproductive strategies, and physiologies. The underlying reason for this pattern is currently not known, and cannot necessarily be explained by chronic hypoxia during development. Embryos of the annual killifish Austrofundulus limnaeus have an unequaled tolerance of anoxia among the vertebrates that is orders of magnitude higher even after developmental stage is taken into account. Despite this high tolerance, they respond to anoxia using the same basic metabolic pathways as more typical vertebrates that lack significant anoxia tolerance. The key to long-term survival of anoxia is the ability to enter a state of profound metabolic depression. Contrary to what is known in other anoxia tolerant vertebrates, ATP levels are not defended in anoxic embryos of A. limnaeus, which indicates a lack of tight coordination between energy production and consumption during transition into anoxia. This evidence suggests that embryos of $A$. limnaeus may have novel mechanisms of anoxia tolerance that have not yet been explored. A better understanding of these mechanisms has the potential to lead to new treatments for diseases and conditions caused by oxygen deprivation in humans. 


\subsection{Preconditioning during vertebrate development}

The induction of preconditioning in developing vertebrates has received very little attention. The few studies that have been reported yield conflicting results depending on the species involved and likely the developmental stage and tissues investigated. In A. limnaeus, embryos with peak tolerance are already prepared for maximal survival of anoxia, and show no positive effects of anoxic preconditioning. Later in development, once this maximal tolerance of anoxia is lost, anoxic preconditioning does induce a protective phenotype. However, preconditioning does not result in recapitulating the lost long-term maximal tolerance of anoxia for this species, or in the other species investigated. This leads to the conclusion that there is something fundamentally different about the molecular phenotype of an embryo following anoxic preconditioning compared to those that naturally express an extremely high tolerance of anoxia as a consequence of their natural developmental program. This is also the case in mammalian systems, where preconditioning of adult tissues is unable to recapitulate the survival times of early life history stages. Thus, the mechanisms that support increased anoxia tolerance during vertebrate development and those that increase tolerance of anoxia due to preconditioning are likely unique. Continued investigation of both strategies has potential to yield a better understanding of anoxia tolerance in developing vertebrates and lead to new treatments for improving survival of oxygen deprivation in humans.

\section{Acknowledgments}

This research was supported by a NIH National Heart Lung and Blood Institute grant to J.E.P (R01HL095454).

\section{References}

Adolph, E.F. (1969). Regulations during survival without oxygen in infant mammals. Respiration Physiology, 7, 356-368.

Adolph, E.F. (1979). Development of dependence on oxygen in embryo salamanders. American Journal of Physiology, 236, R282-R291.

Alchera, E., Dal Ponte, C., Imarisio, C., Albano, E., \& Carini, R. (2010). Molecular mechanisms of liver preconditioning. World Journal of Gastroenterology, 16, 60586067.

Ben-Ari, Y. (2002). Excitatory actions of gaba during development: the nature of the nurture. Nature Reviews Neuroscience, 3, 728-739.

Bharmaa S., \& Milsom, W.K. (1993). Acidosis and metabolic rate in golden mantled ground squirrels (Spermophilus lateralis). Respiration Physiology, 94, 337-351.

Blackstone, E., \& Roth, M.B. (2007). Suspended animation-like state protects mice from lethal hypoxia. Shock, 27, 370-372.

Cai, Z., Fratkin, J.D., Rhodes, P.G. (1997). Prenatal ischemia reduces neuronal injury caused by neonatal hypoxia-ischemia in rats. NeuroReport, 8, 1393-1398.

Ceylan, H., Yuncu, M., Gurel, A., Armutcu, F., Gergerlioglu, H.S., Bagci, C., \& Demiryurek, A.T. (2005). Effects of whole-body hypoxia preconditioning on hypoxia/reoxygenation-induced intestinal injury in newborn rats. European Journal of Pediatric Surgery, 15, 325-332. 
Chambers, D.J., Fallouh, H.B., \& Kassem, N.A. (2010). Ischemic preconditioning and lung preservation, In: Principles of Pulmonary Protection in Heart Surgery, Gabriel, E.A., \& Salerno, T., pp. (223-234), Spinger-Verlag, London.

Chennault, T., \& Podrabsky, J.E. (2010). Aerobic and Anaerobic Capacities Differ in Embryos of the Annual Killifish Austrofundulus limnaeus that develop on Alternate Developmental Trajectories. Journal of Experimental Zoology A, 313A, 587-596.

Cherubini, E., Gaiarsa, J.L., \& Ben-Ari, Y. (1991). GABA: an excitatory transmitter in early postnatal life. Trends in Neurosciences, 14, 515-519.

Cohen, M.V., Yang, X.M., \& Downey, J.M. (1994). Conscious rabbits become tolerant to multiple episodes of ischemic preconditioning. Circulation Research, 74, 998-1004.

Daniel, J.C.Jr. (1968). Oxygen concentrations for culture of rabbit blastocysts. Journal of Reproduction and Fertility, 17, 187-190.

Dawes, G.S., Mott, J.C., \& Shelley, H.J. (1959). The importance of cardiac glycogen for the maintenance of life in foetal lambs and new-born animals during anoxia. Journal of Physiology, 146, 516-538.

Dawes, G.S., Jacobson, H.N., Mott, J.C., \& Shelley, H.J. (1960). Some observations on foetal and new-born Rhesus monkeys. Journal of Physiology, 152, 271-298.

Degos, V., Loron, G., mantz, J., \& Gressens, P. (2008). Neuroprotective strategies for the neonatal brain. Anesthesia \& Analgesia, 106, 1670-1680.

Di Carlo, A.L., \& Litovitz, T.A. (1999). Is genetic the unrecognized confounding factor in bioelectromagnetics? Flock-dependence of field-induced anoxia protection in chick embryos. Bioelectrochemistry and Bioenergetics, 48, 209-215.

Dinkelacker, S.A., Costanzo, J.P., Lee, R.E.Jr. (2005). Anoxia tolerance and freeze tolerance in hatchling turtles. Journal of Comparative Physiology B, 175, 209-217.

DiMichele, L, \& Powers, D.A. (1984). The relationship between oxygen consumption rate and hatching in Fundulus heteroclitus. Physiological Zoology, 57, 46-51.

Duerr, J.M., \& Podrabsky, J.E. (2010). Mitochondrial physiology of diapausing and developing embryos of the annual killifish Austrofundulus limnaeus: Implications for extreme anoxia tolerance. Journal of Comparative Physiology B, 180, 991-1003.

Fazekas, J.F., Alexander, F.A.D., \& Himwich, H.E. (1941). Tolerance of the newborn to anoxia. American Journal of Physiology, 134, 281-287.

Fergusson-Kolmes, L., \& Podrabsky, J.E. (2007). Differential effects of anoxia on heart activity in anoxia-tolerant and anoxia-sensitive embryos of the annual killifish Austrofundulus limnaeus. Journal of Experimental Zoology A, 307A, 419-423.

Gamperl, A.K., Todgham, A.E., Parkhouse, W.S., Dill, R., \& Farrell, A.P. (2001). Recovery of trout myocardial function following anoxia: preconditioning in a non-mammalian model. American Journal of Physiology Regulatory Integrative and Comparative Physiology, 281, R1755-R1763.

Gamperl, A. K., Faust, H.A., Dougher, B., \& Rodnick,K.J. (2004). Hypoxia tolerance and preconditioning are not additive in trout (Oncorhynchus mykiss) heart. Journal of Experimental Biology, 207, 2497-2505.

Gidday, J.M. (2006). Cerebral preconditioning and ischaemic tolerance. Nature Reviews Neuroscience, 7, 437-448. 
Glass, H.G., Snyder, F.F., \& Webster, E. (1944). The rate of decline in resistance to anoxia of rabbits, dogs and guinea pigs from the onset of viability to adult life. American Journal of Physiology, 140, 609-615.

Hall, R. (1925). Effects of oxygen and carbon dioxide on the development of the whitefish. Ecology, 6, 104-116.

Hand, S.C. (1998). Quiescence in Artemia franciscana embryos: reversible arrest of metabolism and gene expression at low oxygen levels. Journal of Experimental Biology, 201, 1233-1242.

Hand, S.C., \& Carpenter, J.F. (1986) pH-Induced Metabolic Transitions in Artemia Embryos Mediated by a Novel Hysteretic Trehalase. Science, 232, 1535-1537.

Hand, S.C., \& Hardewig, I. (1996). Downregulation of cellular metabolism during environmental stress: mechanisms and implications. Annual Review of Physiology, $58,539-563$.

Hochachka, P.W., \& Somero, G.N. (2002). Biochemical Adaptation: Mechanism and Process in Physiological Evolution, Oxford University Press, New York.

Ingalls, T.H., Curley, F.J., \& Prindle, R.A. (1950). Anoxia as a cause of fetal death and congenital defect in the mouse. American Journal of Diseases of Children, 80, 34-45.

Johnson, J., Cobb, G., \& Drew, M.C. (1989). Hypoxic induction of anoxia tolerance in root tips of Zea mays. Plant Physiology, 91, 837-841.

Johnston, I.A., \& Bernard, L.M. (1983). Utilization of the ethanol pathway in carp following exposure to anoxia. Journal of Experimental Biology, 104, 73-78.

Kabat, H. (1940). The greater resistance of very young animals to arrest of the brain circulation. American Journal of Physiology, 130, 588-599.

Krebs, R.A., \& Feder, M.E. (1997). Deleterious consequences of Hsp70 overexpression in Drosphilla melanogaster larvae. Cell Stress Chaperones, 2, 60-71.

Krumschnabel, G. (2000). Cellular and molecular basis of anoxia-tolerance and-intolerance in vertebrates: comparative studies using hepatocytes from goldfish and trout. Recent Research Developments in Comparative Biochemistry and Physiology, 1, 1-11.

Kültz, D. (2003). Evolution of the cellular stress proteome: from monophyletic origin to ubiquitous function. Journal of Experimental Biology, 206, 3119-3124.

Kültz, D. (2005). Molecular and evolutionary basis of the cellular stress response. Annual Review of Physiology, 67, 225-257.

Loeb, J. (1894). Ueber die relative empfindlichkeit von fischembryonen genen sauerstoffmangel und wasserentziehung in verschiedenen enteicklungsstadien. Pflügers Archiv European Journal of Physiology, 55, 530-541.

Longo, L.D., \& Packianathan, S. (1997). Hypoxia-ischaemia and the developing brain: hypotheses regarding the pathophysiology of fetal-neonatal brain damage. BJOG: An International Journal of Obstetrics \& Gynaecology, 104, 652-662.

Lotgering, F.K., Bishai, J.M., Struijk, P.C., Blood, A.B., Hunter, C.J., Oberg, K.C., Power, G.G., \& Longo, L.D. (2004). Absence of robust ischemic preconditioning by five 1-minute total umbilical cord occlusions in fetal sheep. Journal of the Society for Gynecologic Investigation, 11, 449-456. 
Lundmark, J.A., Trueblood, N., Wang L.F., Ramasamyf, R., \& Schaefer, S. (1999). Repetitive acidosis protects the ischemic heart: implications for mechanisms in preconditioned hearts. Journal of Molecular and Cellular Cardiology, 31, 907-917.

Luo, H., Chang, Y., Cai, H., Zou, W., Wng, D., \& Guo, Q. (2008). The effect of hypercapnic acidosis preconditioning on rabbit myocardium. Journal of Huazhong University of Science and Technology -- Medical Sciences, 28, 706-710.

Mendelsohn, B.A., Kassebaum, B.L., \& Gitlin, J.D. (2008). The zebrafish embryo as a dynamic model of anoxia tolerance. Developmental Dynamics, 237, 1780-1788.

Mueller, C.A., Joss, J.M.P., \& Seymour, R.S. (2011). Effects of environmental oxygen on development and respiration of Australian lungfish (Neoceratodus forsteri) embryos. Journal of Comparative Physiology B, 181, 941-952.

Murray C.E., Jennings, R.B., \& Reimer, K.A. (1986). Preconditioning with ischemia: a delay of lethal cell injury in ischemic myocardium. Circulation, 74, 1124-1136.

Mulvey, J.M., \& Renshaw, G.M.C. (2000). Neuronal oxidative hypometabolism in the brainstem of the epaulette shark (Hemiscyllium ocellatum) in response to hypoxic pre-conditioning. Neuroscience Letters, 290, 1-4.

Nelson, O.E. (1958). The development of the primitive streak and early chick embryos in relation to low $\mathrm{O}_{2}$ pressure. Growth, 22, 109-124.

Nilsson, G.E., \& Lutz, P.L. (2004). Anoxia tolerant brains. Journal of Cerebral Blood Flow \& Metabolism, 24, 475-486.

Obrenovitch, T.P. (2008). Molecular physiology of preconditioning-induced brain tolerance to ischemia. Physiological Reviews, 88, 211-247.

Ostadal, B., Ostadalova, I., \& Dhalla, N.S. (1999). Development of cardiac sensitivity to oxygen deficiency: comparative and ontogenetic aspects. Physiological Reviews, 79, 635-659.

Ostadalova, I., Ostadal, B., Kolar, F., Parratt, J.R., \& Wilson, S. (1998). Tolerance to ischaemia and ischaemic preconditioning in neonatal rat heart. Journal of Molecular and Cellular Cardiology, 30, 857-865.

Overgaard, J., Stecyk, J.A.W., Gesser, H., Wang, T., Gamperl, A.K., \& Farrell, A.P. (2004). Preconditioning stimuli do not benefit the myocardium of hypoxia-tolerant rainbow trout (Oncorhynchus mykiss). Journal of Comparative Physiology B, 174, 329340.

Podrabsky, J.E. (1999). Husbandry of the annual killifish Austrofundulus limnaeus with special emphasis on the collection and rearing of embryos. Environmental Biology of Fishes, 54, 421-431.

Podrabsky, J.E., \& Hand, S.C. (1999). The bioenergetics of embryonic diapause in an annual killifish, Austrofundulus limnaeus. Journal of Experimental Biology, 202, 2567-2580.

Podrabsky, J.E., \& Somero, G.N. (2007). An inducible $70 \mathrm{kDa}$-class heat shock protein is constitutively expressed during early development and diapause in the annual killifish Austrofundulus limnaeus. Cell Stress and Chaperones, 12, 199-204.

Podrabsky, J.E., Hrbek, T., \& Hand, S.C. (1998). Physical and chemical characteristics of ephemeral pond habitats in the Maracaibo basin and Llanos region of Venezuela. Hydrobiologia, 362, 67-78. 
Podrabsky, J.E., Lopez, J.P., Fan, T.W.M., Higashi. R., \& Somero, G.N. (2007). Extreme anoxia tolerance in embryos of the annual killifish Austrofundulus limnaeus: Insights from a metabolomics analysis. Journal of Experimental Biology, 210, 22532266.

Podrabsky, J.E., Garrett, I.D.F., \& Kohl, Z.F. (2010a). Alternate developmental pathways associated with diapause in embryos of the annual killifish Austrofundulus limnaeus. Journal of Experimental Biology, 213, 3280-3288.

Podrabsky, J.E., Tingaud-Sequeira, A., \& Cerda, J. (2010b). Metabolic Dormancy and Responses to Environmental Desiccation in Fish Embryos. Topics in Current Genetics, 21, 203-226.

Riddle, O. (1924). On the necessary gaseous environment of the bird embryo. Ecology, 5, 348362.

Rink, R., \& Miller, J.A.Jr. (1967). Temperature, weight (=age) and resistance to asphyxia in pouch-young opossums. Cryobiology, 4, 24-29.

Rose, F.L., Armentrout, D., \& Roper, P. (1971). Physiological responses of paedogenic Ambystoma tigrinum to acute anoxia. Herpetologica, 27, 101-107.

Sedmera, D., Kucera, P., \& Raddatz, E. (2002). Developmental changes in cardiac recovery from anoxia-reoxygenation. American Journal of Physiology Regulatory Integrative and Comparative Physiology, 283, R379-R388.

Shepard, M.P. (1955). Resistance and tolerance of young speckled trout (Salvelinus fontinalis) to oxygen lack, with special reference to low oxygen acclimation. Journal of the Fisheries Research Board of Canada, 12, 387-446.

Shoubridge, E.A., \& Hochachka, P.W. (1980). Ethanol: novel end product of vertebrate anaerobic metabolism. Science, 209, 308-309.

Strackx, E., Van den Hove, D.L.A., Prickaerts, J., Zimmermann, L., Steinbusch, H.W.M., Blanco, C.E., Gavilanes, A.W.D., \& Vles, J.S. Hans. (2010). Fetal asphyctic preconditioning protects against perinatal asphyxia-induced behavioral consequences in adulthood. Behavioural Brain Research, 208, 343-351.

Tyzio, R., Cossaart, R., Khalilov, I., Minlebaev, M., Hübner, C.A., Represa, A., Ben-Ari, Y., \& Khazipov, R. (2006). Maternal oxytocin triggers a transient inhibitory switch in GABA signaling in the fetal brain during delivery. Science, 314, 1788-1792.

van Waarde, A. (1991). Alcoholic fermentation in multicellular organisms. Physiological Zoology, 64, 895-920.

Verdouw, P.D., van den Doel, M.A., de Zeeuw, S., \& Duncker, D.J. (1998). Animal models in the study of myocardial ischaemia and ischaemic syndromes. Cardiovascular Research, 39, 121-135.

Weigmann, A.L., \& Altig, R. (1975). Anoxic tolerances of three species of salamander larvae. Comparative Biochemistry and Physiology A, 50A, 681-684.

Whitfield, N.L., Kreimier, E.L., Verdial, F.C., Skovgaard, N., \& Olson, K.R. (2008). Reappraisal of the $\mathrm{H}_{2} \mathrm{~S}$ / sulfide concentration in vertebrate blood and its potential significance in ischemic preconditioning and vascular signaling. American Journal of Physiology Regulatory Integrative and Comparative Physiology, 294, R1930-R1937. 
Wourms, J.P. (1972a). Developmental biology of annual fishes I. Stages in the normal development of Austrofundulus myersi Dahl. Journal of Experimental Zoology, 182, 143-167.

Wourms, J.P. (1972b) The developmental biology of annual fishes III. Pre-embryonic and embryonic diapause of variable duration in the eggs of annual fishes. Journal of Experimental Zoology, 182, 389-414.

Zhai X, Lawson C.S., Cave A.C., \& Hearse, D.J. (1993). Preconditioning and post-ischaemic contractile dysfunction: the role of impaired oxygen delivery vs extracellular metabolite accumulation. Journal of Molecular and Cellular Cardiology, 25, 847-857. 


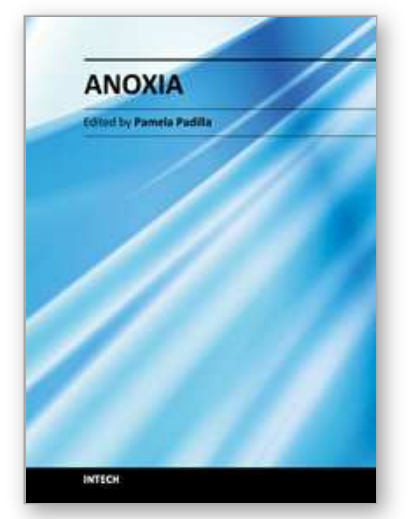

\author{
Anoxia \\ Edited by Dr. Pamela Padilla
}

ISBN 978-953-307-664-5

Hard cover, 146 pages

Publisher InTech

Published online 05, January, 2012

Published in print edition January, 2012

This book reviews how severe oxygen deprivation affects biological systems - from the molecular to the ecological level. The contributing authors come from diverse regions of the world, which proves the interest in the academic analysis of oxygen deprivation. The diversity in the experimental approach scientists take, in order to understand the influence oxygen deprivation has on living systems, is apparent throughout this book. One of the presented ideas deals with the exploration and examination of the physiological, cellular and genetic characteristics of killifish embryos and nematodes exposed to anoxia. Furthermore, the book includes material on the mechanisms regulating hypoxia and anoxia tolerance and their implications of on human health issues. Finally, new methodologies to examine oxygen deprivation and the impact of human-related activities on oxygen level, within important ecological systems such as Lake Victoria, are presented. There is no doubt that the oxygen molecule is central to every stratum of biological systems.

\title{
How to reference
}

In order to correctly reference this scholarly work, feel free to copy and paste the following:

Jason E. Podrabsky, Claire L. Riggs and Jeffrey M. Duerr (2012). Anoxia Tolerance During Vertebrate Development - Insights from Studies on the Annual Killifish Austrofundulus limnaeus, Anoxia, Dr. Pamela Padilla (Ed.), ISBN: 978-953-307-664-5, InTech, Available from:

http://www.intechopen.com/books/anoxia/anoxia-tolerance-during-vertebrate-development-insights-fromstudies-on-the-annual-killifish-austrof

\section{INTECH}

open science | open minds

\section{InTech Europe}

University Campus STeP Ri

Slavka Krautzeka 83/A

51000 Rijeka, Croatia

Phone: +385 (51) 770447

Fax: +385 (51) 686166

www.intechopen.com

\section{InTech China}

Unit 405, Office Block, Hotel Equatorial Shanghai

No.65, Yan An Road (West), Shanghai, 200040, China

中国上海市延安西路65号上海国际贵都大饭店办公楼 405 单元

Phone: +86-21-62489820

Fax: $+86-21-62489821$ 
(C) 2012 The Author(s). Licensee IntechOpen. This is an open access article distributed under the terms of the Creative Commons Attribution 3.0 License, which permits unrestricted use, distribution, and reproduction in any medium, provided the original work is properly cited. 